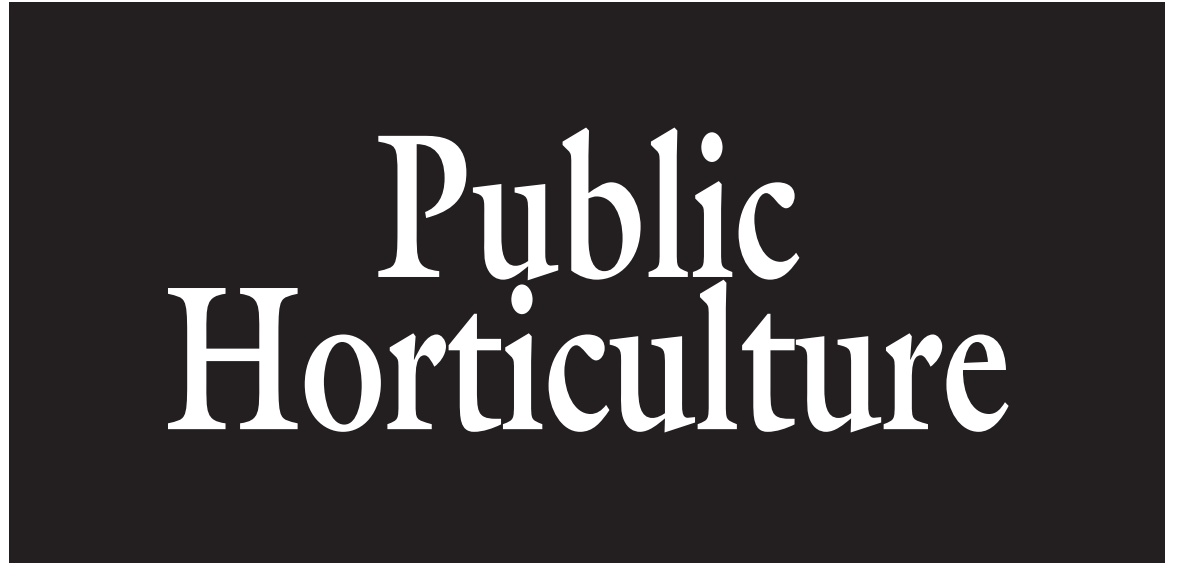

\section{Palma Corcho: A Case Study in Botanic Garden Conservation Horticulture and Economics}

\author{
Judy Kay, Arantza A. Strader, Vickie Murphy, Lan Nghiem-Phu, \\ Michael Calonje, and M. Patrick Griffith ${ }^{1}$
}

AdDitional INDEX WORDs. cycad, ex situ conservation, Microcycas calocoma, pollen viability

SUMMARY. Horticulture is an essential part of plant conservation programs, and botanic gardens are uniquely suited for conservation horticulture work. Here, we present a case study of a successful cycad (Cycadales) propagation program at Montgomery Botanical Center (MBC, Miami, FL), using palma corcho (Microcycas calocoma) as an example. This species is highly sought in the nursery trade, and overcollection of wild plants is one factor leading to imperilment of natural populations. Thus, propagation and distribution of palma corcho can make a strategic contribution to in situ conservation. Provenance history of the living collections is reviewed, and techniques for propagation and establishment are detailed. An innovative botanic garden/industry partnership to provide seed for cultivation is discussed. Finally, we present analysis of market forces with regard to rare plant availability and conservation, using palma corcho as an example. Average price per seed has fallen by over half since offered on public auction. This inversely correlates with seed supply, which has been steadily increasing during the last 15 years and helping meet the high market demand. We project the cost of palma corcho will fall further to a point where collection from the wild has no further economic incentive.

$\mathrm{B}$

otanic gardens increasingly work to advance conservation (Oldfield, 2010, among others),

Montgomery Botanical Center, 11901 Old Cutler Road, Coral Gables, FL 33156

The authors thank Ramona Oviedo for access to the Herbarium of the Instituto de Ecología y Sistemática (HAC); Ian Simpkins for providing the information from the Vizcaya Archive; Stella Cuestas and Marino Valcourt for stewarding these plants; Vivian Jordan, Larry Krauss, Bernard Scherban, Karl Smiley, and Bettye Douglas for tireless volunteer efforts in the Seedbank; Vivian Jordan for discussion on the subject of thermogenesis and odor; John DeMott for his development of the seedbank partnership; Tracy Magellan, Chad Husby, Karin van der Walt, Robert Lyons, Neal De Vos, and two anonymous reviewers for constructive feedback; the City of Coral Gables for support; and Christiane Tyson for providing the Chris Tyson Plant Conservation Building-our cycad breeding headquarters

${ }^{1}$ Corresponding author. E-mail: patrick@montgomery botanical.org. and like zoos, many gardens have adopted conservation as one of their primary missions. Conservation horticulture is an area of work that leverages staff expertise and established physical et al., 2011). It is also a conservation task not traditionally served by other organizations (Griffith et al., 2011). Well-established techniques of ex situ conservation horticulture make this capacity at botanic gardens (Kramer area of work a clear path forward for the modern public garden.

Cycad species are broadly imperiled by habitat loss. An additional consistent threat to cycads remains illegal collection in the wild (Donaldson, 2003). Cycads fascinate the public with unusual form, antiquity and association with dinosaurs. They are also useful for research and education in plant evolution, morphology, and conservation issues. For these reasons, living cycads are featured at public gardens and conservatories.

All cycads are dioecious and insect pollinated and this necessitates active propagation by garden staff, as pollinators are typically not present. Thus, cycads include some of the clearest examples of conservation horticulture. Most famous is wood's cycad (Encephalartos woodii), known only in cultivation, with all plants clonally derived males from the sole remaining wild plant which was brought into protective cultivation in the early 20 th century (Prakash et al., 2008). Other examples include projects to propagate debao cycad [Cycas debaoensis (Tang et al., 2004)], chestnut dioon [Dioon edule (Vovides, 2010)], zamias [Zamia spp. (Calonje et al., 2010; Griffith et al., 2010)], and micronesian cycad [Cycas micronesica (Griffith and Calonje, 2007)]. In the interests of further advancing cycad conservation horticulture, the MBC Seedbank has placed its major emphasis on propagating and distributing cycads. Cycad seeds produced at MBC are shared with public gardens (Table 1), schools, conservationists, and researchers. After these distributions are made, collectors and the horticulture industry are given a chance to purchase seeds of these rare species legally. Data from these purchases can help inform supply and demand of this species in cultivation, which can have implications on overcollection of wild populations.

\section{Model system: Palma corcho}

Palma corcho (cork palm), the sole species in the genus Microcycas, is

\begin{tabular}{llll}
\hline $\begin{array}{l}\text { Units } \\
\begin{array}{l}\text { To convert U.S. to SI, } \\
\text { multiply by }\end{array}\end{array}$ & U.S. unit & SI unit & $\begin{array}{l}\text { To convert SI to U.S., } \\
\text { multiply by }\end{array}$ \\
\hline 0.3048 & $\mathrm{ft}$ & $\mathrm{m}$ & 3.2808 \\
3.7854 & $\mathrm{gal}$ & $\mathrm{L}$ & 0.2642 \\
2.54 & inch $(\mathrm{es})$ & $\mathrm{cm}$ & 0.3937 \\
$\left({ }^{\circ} \mathrm{F}-32\right) \div 1.8$ & ${ }^{\circ} \mathrm{F}$ & ${ }^{\circ} \mathrm{C}$ & $\left(1.8 \times{ }^{\circ} \mathrm{C}\right)+32$
\end{tabular}


Table 1. Records show that 13 public horticulture institutions have received palma corcho seed from Montgomery Botanical Center (Coral Gables, FL).

\begin{tabular}{ll}
\hline Public horticulture institution & \multicolumn{1}{c}{ Location } \\
\hline Botanic Garden of Smith College & Northampton, MA \\
Fairchild Tropical Botanic Garden & Miami, FL \\
Fullerton Arboretum & Fullerton, CA \\
Ganna Walska Lotusland & Santa Barbara, CA \\
Hortus Botanicus Amsterdam & Amsterdam, Netherlands \\
Hortus Botanicus Leiden & Leiden, Netherlands \\
Kirstenbosch National Botanical Garden & Cape Town, South Africa \\
National Tropical Botanical Garden & Kalaheo, HI \\
New York Botanical Garden & New York, NY \\
Pretoria National Botanical Garden & Pretoria, South Africa \\
Rio Grande Botanical Garden & Albuquerque, NM \\
Singapore Botanic Gardens & Singapore \\
Strybing Arboretum and Botanical Garden & San Francisco, CA \\
\hline
\end{tabular}

a Cuban endemic cycad, closely related to zamias, and occurring in the Pinar del Rio province. The arborescent plants can grow as tall as $11 \mathrm{~m}$ (Lazcano, 2007) and have very attractive truncate leaf morphology and reflexed semipendent leaflets, giving the plants a formal, almost topiary quality. This is a prized ornamental New World cycad (Jones, 1993), much sought after by collectors.

Native populations of palma corcho have been assessed as "critically endangered," the highest risk International Union for Conservation of Nature category for wild species due to severe recent decline of population size (Bösenberg, 2009; Peña et al., 1998). Estimates of living wild plants range from 600 (Jones, 1993; Whitelock, 2002) to 1540 (Bösenberg, 2009) or perhaps as high as 4000 with projections for further decline (Bösenberg, 2009). Experts cite collection for ornamental purposes, habitat destruction, reduced natural reproduction rates, reduction of natural pollinators, and predation by exotic herbivores as contributing to the decline of the species (LazcanoLara, 2004; Pinares et al., 2009; Vovides et al., 1997). As stated by Julio Lazcano (2007), a leading expert on the wild populations of palma corcho, one conservation strategy for this species is to "cultivate ex situ collections for future reintroduction, exchange, or controlled sales."

To advance this line of work, we present here a case study of a botanic garden cycad propagation program, focused on this exemplar, palma corcho. This model system presents a highly coveted, critically imperiled plant, with limited breeding stock and challenging propagation circumstances.

\section{Provenance of MBC palma corcho}

In 1915, industrialist James Deering acquired a large shipment of mature royal palms (Roystonea) for landscaping his Miami, FL estate, Vizcaya. These came to Vizcaya from H.A. van Hermann (Gayer, n.d.). Mr. van Hermann was Treasurer of the Cuban National Horticultural Society (CNHS) and an official of the Cuban Agricultural Department (CNHS, 1911). Van Hermann collected palma corcho in the field in late 1914 (Fig. 1). Included in the Vizcaya shipment were several palma corcho plants. The plants had between 3 and $5 \mathrm{ft}$ of trunk at that time (Sturrock, 1915) and were estimated to be around 40 years old and dug from the wild (Calonje, 2007). The cycads were planted in tubs and displayed by the front entrance to the Deering home and in the terra cotta garden.

In 1932, Colonel Robert Montgomery began developing the plant collection at the Coconut Grove Palmetum (now MBC). As part of this effort, Montgomery acquired two palma corcho plants from the Deerings for $\$ 90$ (Calonje, 2007), roughly equal to $\$ 1450$ in 2010 . In 1932, the two plants were then 5 and $8 \mathrm{ft}$, respectively. The smaller one (accession RM384) survives at MBC (Figs. 2 and 3). This male plant (nicknamed "Grandfather") is the source of much pollen. In 2010, this plant was named a "champion tree" by the Florida Division of Forestry and is likely the largest palma corcho outside of Cuba. Colonel Montgomery

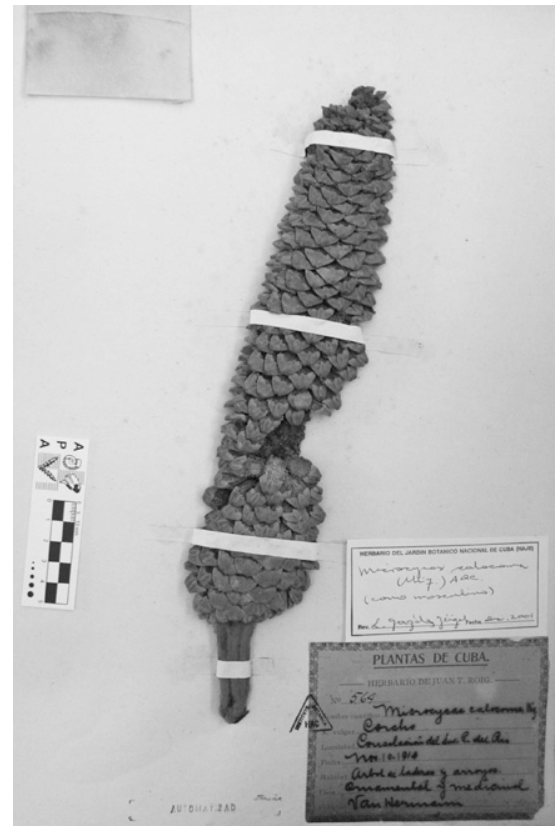

Fig. 1. This palma corcho specimen (van Hermann 564, from Herbarium of the Instituto de Ecología y Sistemática, Havana, Cuba), showing a male cone, was collected from the field by H.A. van Hermann in Pinar del Rio, Cuba, in 1914, a few months before the plants were shipped to Vizcaya.

donated the larger plant (also a male) to Fairchild Tropical Botanic Garden (FTBG, Miami, FL) when he established the garden in 1938.

Since all known palma corcho material in the United States at that time was male, Stanley Kiem (from FTBG) and Marcial Truffin (a Cuban horticulturist) collected additional material in Cuba expressly for propagation in 1959 (Kiem, 1963). Two plants survived to produce cones. The first plant, a male, produced cones in 1974, whereas the other plant, a female, produced cones in 1977. These two plants were crossed and produced seeds in 1977 (Calonje, 2007). Lightning in 1991 destroyed the sole female plant from the 1959 fieldwork. Three years later (1994), the plants grown from seeds sown in 1977 began to produce female cones. MBC began hand-pollinating these plants in 1995 and distributed the first seeds in 1996. Thus, the 1977 garden-propagated females comprise entire seed source for the last two decades. Lack of material in cultivation is reflected by data from Botanic Gardens Conservation International (2011), which shows palma corcho is found in only 32 plant collections worldwide. 


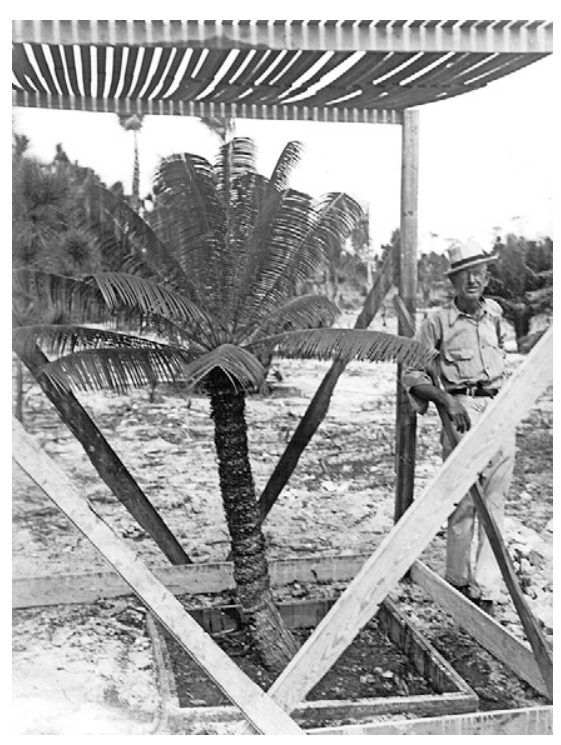

Fig. 2. The palma corcho (accession number RM384) in this 1932 photograph was established as one of the first cycads at Montgomery Botanical Center, Coral Gables, FL. J.E. Hendry Jr., a prominent horticulturist from Fort Myers, provides scale.

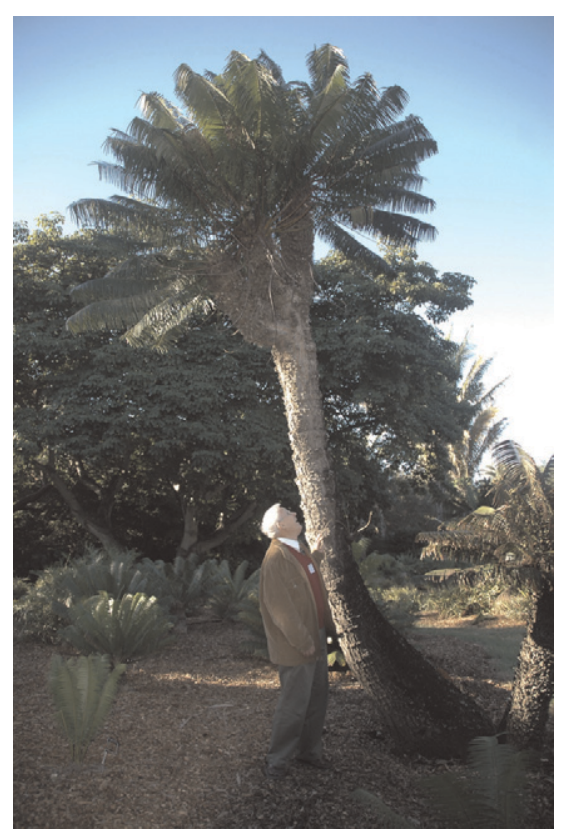

Fig. 3. This palma corcho (accession number RM384) has grown to a crown height of $4 \mathrm{~m}(13.1 \mathrm{ft})$, at Montgomery Botanical Center, Coral Gables, FL. The plant is estimated to be around 135 years old. J. Popenoe, Retired Director of Fairchild Tropical Botanic Garden, Coral Gables, FL, provides scale in this 2010 photograph.

MBC has provided material to 13 public horticulture institutions (Table 1), although certainly the 32 and 13 gardens do not overlap completely.
This history emphasizes how redundancy planning, plant exchange, and active propagation of living plant collections help mitigate unplanned loss by natural disasters (Bergquist, 2009, 2010; Dosmann and Del Tredici, 2003). In summary, the MBC living palma corcho collections that comprise propagation stock have an eclectic history and were not deliberately developed with genetic diversity or reintroduction as an a priori goal (Maunder et al., 2004; Radford et al., 2003).

\section{Phenology and pollination}

In habitat, male and female cones are reported to take 4 months to develop, with pollen shedding/receptivity occurring in September, and seed maturation occurring 10 months later in July (Whitelock, 2002). In cultivation, Norstog and Nicholls (2002) report that female plants produce a single cone every other year, pollinated in September, and persisting until the following June, and that male cones mature in July or August, with pollen shed in early September. We find that the peak in receptivity for female cones of palma corcho in Miami, FL, occurs in August, with some receptivity events also occurring in July and September (Fig. 4). Coning for some female individuals can occur in consecutive years, and 1 or 2 female cones may be produced in a single coning event, typically borne from separate apices. Male cones in the $\mathrm{MBC}$ collection release pollen in August and September. Whitelock (2002) mentions that an 8-year-old palma corcho plant can bear cones, but Norstog and Nicholls (2002) state that 10-15 years are needed. At MBC, the earliest female coning event occurred after 18 years from seed, and the youngest male coning event occurred after 9 years.

Cycad cones are often known to generate considerable heat, thermogenesis, during receptivity (Tang et al., 1987), which is also linked to the production of volatile olfactory compounds (Tang, 1993). Although these odors are adapted for insects [thrips (Thysanoptera) and weevils/beetles (Coleoptera)], humans can often detect these odors and describe cycad cones as smelling "musty, fruity, or sweet" (Whitelock, 2002). Odors produced in burrawang (Macrozamia lucida) attract and repel pollinators to facilitate pollen transfer (Terry et al., 2007). We observe that both male and female palma corcho cones have a

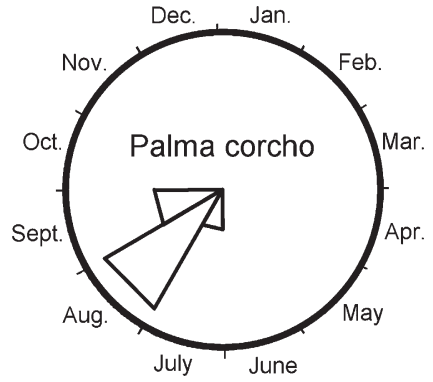

Fig. 4. This phenograph shows reproductive phenology of palma corcho (adapted from Griffith et al., $2011 b$ ). Wedges indicate proportion of observed female cone receptivity or male pollen shedding events ( 73 events recorded among 21 plants) in each month. Data were collected over the course of 13 years (each plant observed 156 times). Reproductive events for palma corcho begin in July, peak strongly in August, and are also observed in September.

musty odor at pollen release. Whitelock (2002) describes this odor as "strongly disagreeable." The mature female cones at $\mathrm{MBC}$ produce a scent some people find disagreeable, which is likely produced by ripe sarcotesta (personal observation). Esperanza's weevil (Pharaxonotha esperanzae), the pollinator of palma corcho, was only recently documented and described (Chavez and Genaro, 2005), after having been assumed near-extirpated (Vovides et al., 1997).

\section{Male cones-pollen collection, storage, and viability testing}

Pollen Collection. Male cones in the MBC collection mature and release pollen mainly in August. During this process, the cones elongate, the microsporophylls separate, and the pollen sacs (microsporangia) break apart to release pollen. If female cones are receptive at the same time, then freshly collected pollen is used for pollination, but if female cones are not yet receptive, pollen is collected and processed for storage. When the male cone begins releasing pollen, the cone is removed from the plant and placed on a tray on waxed butcher paper (Fig. 5 ) in a shady, cool location. It must be kept separate from other cones and out of drafts. The cone is tapped daily for $\approx 4 \mathrm{~d}$ with a small wooden mallet to stimulate pollen release.

Storage. The shed pollen is cleared of debris and placed in small 


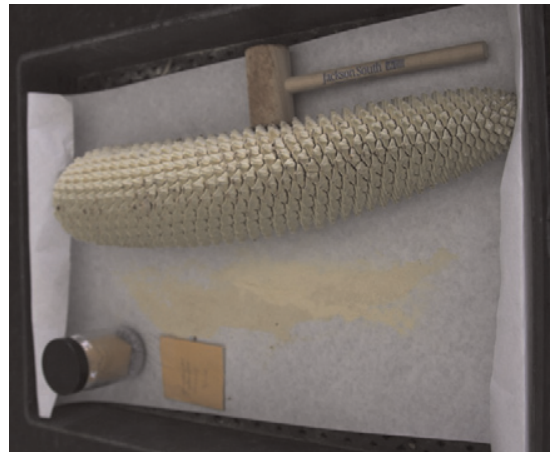

Fig. 5. This male cone of palma corcho is shedding pollen which will be collected, desiccated, and stored at freezing temperature for future use.

paper envelopes that are subsequently placed in airtight glass jars containing silica gel desiccant. The jars are kept in the refrigerator for at least $2 \mathrm{~d}$ to absorb the moisture from the pollen and can then be transferred into $\mathrm{a}-2{ }^{\circ} \mathrm{C}$ freezer where it will remain viable for up to 3 years. A non-self-defrosting home freezer is preferred as the temperature remains more constant, although properly prepared pollen in airtight jars will keep well in self-defrosting freezers (Hanna, 1994). Pollen is routinely donated to other botanical gardens (FTBG and Gemini Garden, Manalapan, FL) and to nurseries.

Viability testing. Pollen viability can be tested by preparing a slide with aniline blue stain. After setting for 12-24 h, viable pollen grains will stain dark blue when examined with a compound microscope (Fig. 6). A standardized protocol using aniline blue in phenol/lactic acid is used (Hauser and Morrison, 1964). Pollen older than 2 years is routinely tested, and pollen with low viability (generally less than $25 \%$ ) is discarded.

\section{Female cones-receptivity and pollination}

When female cones are receptive, they show large longitudinal fissures between the megasporophylls. Female cones usually stay receptive for at least 1 week. Although many cycads are propagated through a wet pollination, we use a dry pollination for palma corcho as the embryos have shown to be susceptible to a fungal pathogen (personal observation). This pathogen is currently in the process of being identified. The pollen is blown into the fissures with a hand-bulb compression tool on three different days during the receptivity period (Fig. 7). As the seeds mature, the cones become pendulant and heavy so as a precaution we often support them with a wooden brace to ensure they do not fall off prematurely due to weight.

\section{Seed collection, viability, germination, and care}

Female cones take an average of $310 \mathrm{~d}$ to mature. As the female cone matures, we let the seeds stay on the cone as long as possible and disarticulate naturally (Fig. 8). The seeds are usually collected over an 8-d period. Between 500 and 600 seeds are produced per cone. Viability is determined by cutting into $\approx 20$ seeds and observing whether embryos are present. Not all seeds with embryos will germinate, but due to the brief viability of seeds, germination testing before seed distribution is not possible and viability testing is the best indication available of whether there is a possibility that germination will occur. Past viability rates have varied from as low as $0 \%$ to as high as $90 \%$, and average $45 \%$.

Palma corcho seed is highly recalcitrant and must be sown while very fresh or at least within 4 months (Whitelock, 2002). Under favorable conditions, seed will germinate in $2-3$ weeks. Seeds are distributed with the fleshy sarcotesta attached (uncleaned), but in good practice are cleaned and sown immediately by the recipient. At MBC, we treat the seed for fungus (after cleaning) with hydrogen peroxide (ZeroTol; BioSafe Systems, East Hartford, CT). Well-drained media are required, and we use silica sand for germination, and then inorganic media in subsequent repottings (e.g., Turface MVP; Turface Athletics, Buffalo Grove, IL) to maintain long-term drainage and minimize rotting problems that can develop with organic media (Calonje et al., 2010). Germination rates (which are always lower than viability rates) vary with differing cultivation practice, but range from $0 \%$ to $60 \%$ and average $26 \%$ at MBC. Seeds are sown directly in community pots after cleaning, and first germination occurs within 5 months. MBC uses community pots (10-20 seeds in a 2 -gal container) initially as we experience fewer rot problems with this method (as opposed to single seeds in single containers). This advantage is

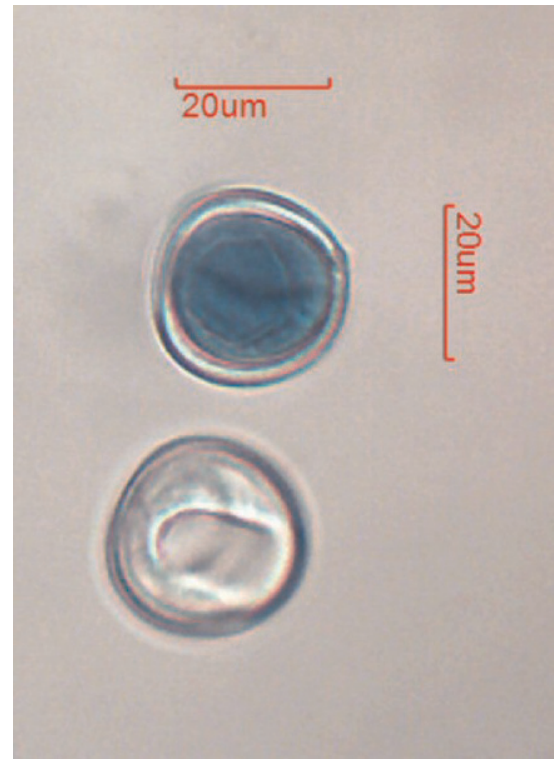

Fig. 6. Stored palma corcho pollen is routinely tested for viability. When stained with aniline blue stain (Hauser and Morrison, 1964), viable pollen grains appear blue (top grain). This pollen (from accession number $77404^{*} \mathrm{P}$ ) had been in cold storage for 10 months at testing.

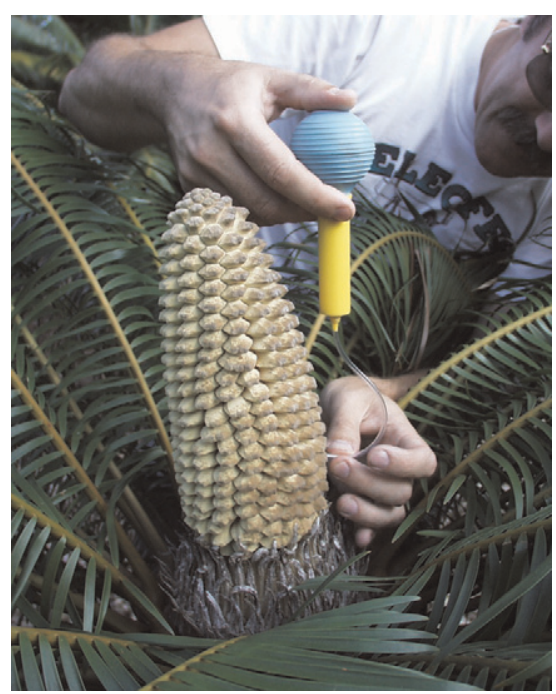

Fig. 7. Montgomery Botanical Center (Coral Gables, FL) volunteer Larry Krauss is pollinating a receptive female cone (accession number $77404 * \mathrm{G}$, one of the 1977 seedlings). Note the vertical fissures between the cone scales, which indicate the receptive period.

likely due to the deeper containers that can be used in contrast to single-seed containers. Seedlings are repotted from community pots to individual pots 6 to 8 months after germination. Seeds and seedlings are hand-watered 


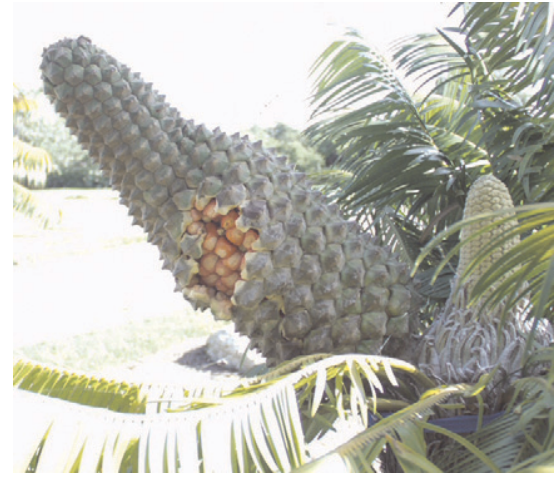

Fig. 8. This palma corcho (accession number $77404^{*} G$ ) female cone shows mature seeds in this photo from late June. The natural disarticulation of the cone scales releases the mature seed. The blue tape (lower right, behind foliage) indicates that this cone has received artificial pollination.

using city water three times per week (or as needed). Nursery seedlings are fertilized with $18 \mathrm{~N}-2.6 \mathrm{P}-6.6 \mathrm{~K}$ slowrelease fertilizer (Nutricote; Florikan, Sarasota, FL) at each repotting (every 6 months on average). At MBC, germination work is performed in a $20 \times$ 60-ft glasshouse with temperatures ranging from 60 to $80^{\circ} \mathrm{F}$.

Palma corcho plants are reported to be very susceptible to fungus in the first 2 years after germination. MBC has not yet observed this problem, and this is likely due to consistent use of freely draining media, and especially inorganic media (Fig. 9). ZeroTol is also used at this stage to treat fungus, applied directly to plant surfaces. Good airflow in the greenhouse (i.e., lack of overcrowding) may also help. Palma corcho are also prone to hemispherical scale (Saissetia coffeae) in the nursery. For hemispherical scale, the plants are hand-cleaned with a soft toothbrush and then treated with dinotefuran (Safari; Valent Professional Products, Walnut Creek, CA), a broad spectrum insecticide. Dinotefuran is also used as a drench, per the manufacturer's specifications.

Once the trunk is established, palma corcho is reputed to be a fast growing cycad that can produce $10-20 \mathrm{~cm}$ of stem per year in subtropical climates (Whitelock, 2002). Our 1977 plants are now $\approx 6$-ft tall. Palma corcho will defoliate in frost and prefers to be kept drier in the winter. At MBC, palma corcho with rot problems are treated with hydrogen peroxide after cutting away infected tissues. For the hemispherical scale, infested leaves are trimmed and the crown washed and treated with dinotefuran if needed. Used coffee grounds are also placed around the base of the trunk as mulch as this is reputed to suppress scale insects (Broome, 2007). Plants on the grounds are fertilized with a high-quality palm fertilizer $(8 \mathrm{~N}-1.7 \mathrm{P}-10.0 \mathrm{~K})$.

\section{Using the market to support conservation}

In the mid-1990s, MBC and the Florida Nursery, Growers and Landscape Association (FNGLA, Orlando, FL) developed a partnership to distribute seed produced from MBC's living collections. An abundance of uniquely provenienced breeding stock and a market for novel material were waiting to come together. By carefully following permitting requirements [Convention on International Trade of Endangered Species (CITES)] and ethics, an innovative process developed to use the market to advance conservation horticulture.

Palma corcho seeds produced at MBC have been distributed to many botanic gardens over the years (Table 1). After such research, education and conservation distributions are made, excess seed supply could be distributed to the domestic horticulture industry, where the market demanded new plants. Income from this activity could then be used to support the staffing and supplies needed for the propagation work. In 1998, a group of horticulture industry shareholders provided the initial capital for $\mathrm{MBC}$ and FNGLA to hire a seedbank coordinator, and those shareholders received that year's excess seed. An online auction (FNGLA, 2011) was begun in the mid-2000s, enabling the supplier and consumer to each streamline their participation in the market. This auction also provides a direct source of data about the market for cycads. Per the legal and permitting framework under CITES, auction of seeds is limited to within the United States.

Supply. Before the MBC-FNGLA Seedbank establishment, an average of 560 palma corcho seeds per year were distributed from MBC in 1996 98 (Fig. 10). A fungus problem in 1999 precluded distribution that year. From 2000-02, MBC was able to distribute and average of 950 seeds per year. Another fungus issue in 2003 reduced the seed volume, and

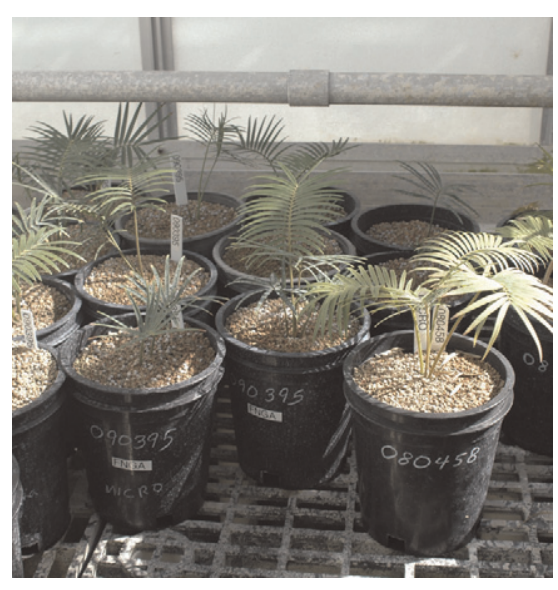

Fig. 9. Palma corcho seedlings from Montgomery Botanical Center (Coral Gables, FL) propagations are grown in an inorganic medium. The plants marked 090395 are 1.5 years from sowing, and those marked 080458 are 2.5 years from sowing in this Dec. 2010 photograph. Like many cycads, palma corcho is a slow-growing plant, especially as a seedling. Slow growth rate can be an obstacle to development for ornamental horticulture.

the female plants were then given a fallow period in 2004 and 2005 for treatment and recuperation. This appeared to work well, as numbers of seeds distributed slowly rose, reaching an average of 1000 seeds per year from 2007-09. The apex was reached in our last distribution (2010) with 2155 seeds produced from three hand-pollinated cones. So, using the living assets (eclectically developed from 1915 through the present) and investing in propagation (staffing and equipment) has robustly increased the supply of palma corcho.

DEMAND. Tracking palma corcho seed shows the expected trend relative to increased supply: steady decline in the price per seed. Palma corcho seed first appeared on auction in 2007. Seeds are auctioned in lots of a few hundred, depending on the total amount available each year. The average price per seed first rapidly declined (Fig. 11), from its all time high at initial offering to a consistently declining price trend from 2008 to 2010. This remains a higher price than any other seed offered by MBC, but the effects of increased supply appear to have consistently lowered the price.

Value. Looking at price per seed without context (Fig. 11), decreased value is the first impression. But we assert that for purposes of conservation, 


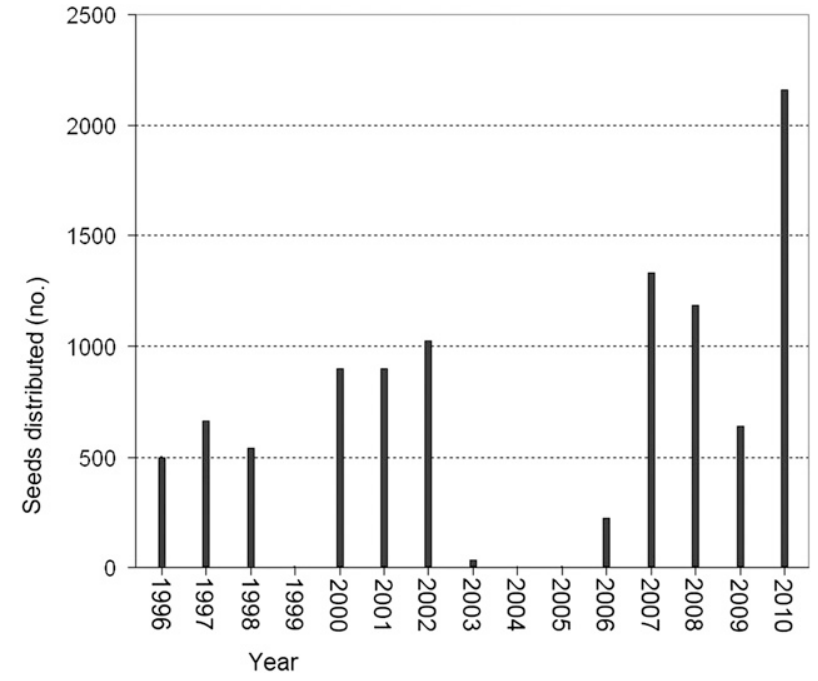

Fig. 10. Palma corcho seed have been distributed by Montgomery Botanical Center, Coral Gables, FL, since 1996. There is a generalized trend toward increased output of seed per year over the last 15 years. Seeds were not distributed in 1999 and 2004 05 due to a fungal pathogen.

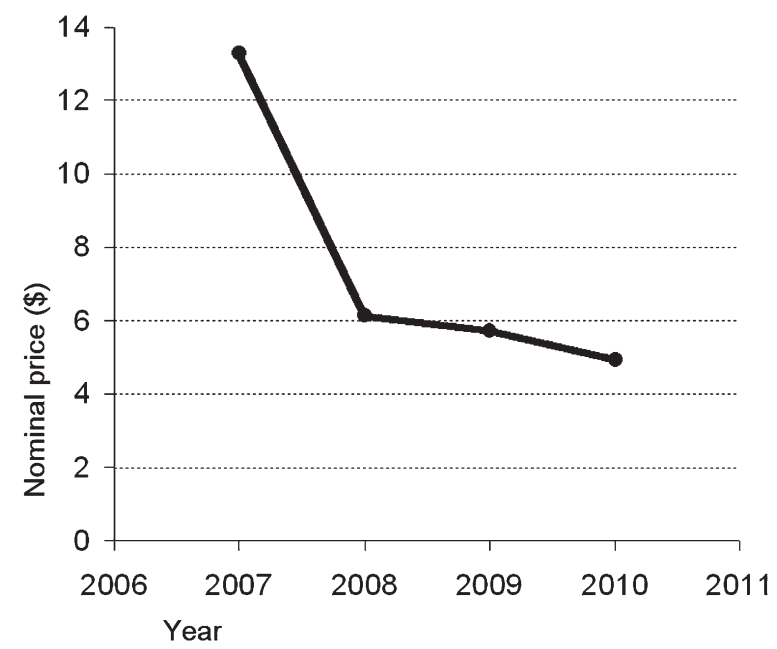

Fig. 11. Auction results show average nominal price per palma corcho seed has declined over time. Normalization of these values to adjust for inflation (constant 2007 dollars) or economic recession (constant 2007 Gross Domestic Product) does not alter the trend. The initial offering of seed in 2007 commanded the highest average price, followed by an immediate steep drop in price, and a steady decline thereafter.

acting to lower the commercial value of rare plants is a positive strategic contribution. Widespread availability of cycads in the nursery trade can reduce illegal collection or theft of living collections. For an especially coveted species like palma corcho, depressing the market price is part of an integrated strategy for reducing poaching as it removes the incentive.

Projection. What will the future market for palma corcho look like? The trends in Figs. 10 and 11 show a steady increase in supply and a steady decrease in price. Informal reporting among auction participants indicates that seeds obtained through the seedbank are germinating, and some are making it past the critical seedling stages. Thus, not only are young $\mathrm{MBC}$-sourced seedlings being grown for the specialty collector's market, but at some point in the near future, an increasing number of nurseries will have reproductively mature plants to use in their own propagation activities.

Using the range of age at first coning times reported above (8-10 year minimum), coning plants could have been derived from MBC seed distributions potentially as early as 200406 and have been increasingly likely since that year. With further development of container culture techniques for accelerating cycad growth (e.g., Calonje et al., 2010; Dehgan, 1999), a broader market may also see sufficient volume of inexpensive plants within a decade.

\section{Palma corcho as a model system}

Palma corcho serves as an example for conservation horticulture, demonstrating the use and management of living collections to create a measurable outcome. Using palma corcho as a model system for plant conservation can illustrate some principles, but this model system also will not apply in every case. Below, we discuss how this example works as a model and its appropriateness of fit.

In this case study, we explore the management of a difficult to obtain plant (Jones, 1993), under threat of overcollection from the wild (Lazcano, 2007). Another case study from MBC used a model species [keys thatch palm (Leucothrinax morissii)] not under immediate collecting threat to explore capture of genetic diversity (Namoff et al., 2010). So, the current model system has the potential to illustrate cases in which pressure from collectors is a factor. In the current study, we also can see the intensive input of resources needed to manage a living collection of cycads for breeding purposes (managing pollen, monitoring phenology, active breeding, and distribution of seed). In contrast, the keys thatch palm collection did not require such a high level of specialization to manage (Griffith and Husby, 2010).

In the current case, the living collections were slowly developed beginning nearly a century ago, through historical trade, field collections, and intensive propagation. This collections development was eclectic (rather than systematic), and at first primarily motivated for display, rather than for ex situ conservation. Based on political, legal, historical, and market factors, the limited palma corcho collections became an important asset despite lack of detailed field provenance data or broad sample size, the hallmarks of modern plant conservation management (Lawrence et al., 1995). Also 
contributing to this example are biological circumstances, including a very long generation time and obligate specialized pollination (Vovides et al., 1997). Unplanned loss by natural disaster (e.g., Griffith et al., 2008) plays in role in this case as well; current palma corcho breeding stock is further inbred by loss of some of the 1959 collections and is now limited to the descendants of the 1915 male plant and the 1959 plants.

Economic data are especially informative for this model system. Of all seeds offered through the online auction, palma corcho have earned the highest price each year they were available. This reflects the prized nature of this species for collectors, which translates to demand for seed by nurseries. One potential concern with these data may be the confounding effects of the 2008 economic crisis on the seed price-was the drop in price between 2007 and 2008 related to supply or did general economic conditions play a role? To test this, we applied corrective factors, transforming the data to constant 2007 dollars or constant 2007 gross domestic product. With the corrective factors applied, the trend in seed price still shows a steep and then steady decline in value. Furthermore, auction of palma corcho occurs when seed are fresh (June and July) so the effects of the Oct. 2008 economic crisis do not likely contribute to the 2007-08 reduction in seed price.

The relationship between economics and conservation is well established, mostly for animal poaching (e.g., Bulte and van Kooten, 1999). For plants, the literature is largely focused on overcollection for medicinal use, although the production of wollemi pine (Wollemia nobilis) can provide a nonmedicinal example (Trueman et al., 2007). Studies examined medicinal plants in arid Mexico (HerschMartínez, 1995), the Himalayan Alpine (Chandra et al., 2006; Smith Olsen and Overgaard Larsen, 2003), and Brazil (de Melo et al., 2009; Homma, 1992). In one example reflecting the current study, unofficial market price was shown to rise with high demand and scarce supply, and therefore increased cultivation was expected to support in situ conservation (Chandra et al., 2006).

The palma corcho model system can bring this concept of conservation economics into public horticulture.
This model shows that leveraging legacy botanic garden collections to produce and distribute seed can go a long way to meet market demand for rare plants. As in the examples cited above, lowered market value should correlate with a greatly reduced incentive to obtain plants dug from the wild.

\section{Limitations and areas for improvement}

Ideally, plant conservation collections should aim for broad capture of genetic diversity (Namoff et al., 2010). Given the well-documented history of these few plants, genetic diversity of the palma corcho living collections at $\mathrm{MBC}$ is certainly limited. Thus, stock produced from these plants alone would not be ideal for reintroduction purposes. Pollen viability is always less than $100 \%$, and seed viability is always less than $90 \%$. This is likely due to inbreeding depression, given the known limited pedigree of these plants (Hedrick and Kalinowski, 2000). Increased diversity via newly collected plants would be of great benefit to the system.

Feedback from recipients of the palma corcho seed has been variable. Observed pollen viability, seed viability, and germination rates at $\mathrm{MBC}$ have consistently been less than $100 \%, 90 \%$, and $70 \%$, respectively. Seed viability has been transparently reported through the auction website. Perhaps given the elevated price of these seed, expectations of return on investment have been high, and some misunderstandings have conflated the reported seed viability with expected germination rate. Additionally, a fungal pathogen has been observed in some seed. Concerned feedback from seed recipients has helped to shape the seedbank program's communication and prompted MBC to send seed samples to experts at the University of Florida for fungal pathogen isolation and identification (currently underway). Continued improvement of communication with purchasers can help clarify differences in seed viability and germination rate and also promote good cultivation practice.

\section{Conclusion and future outlook}

Effective conservation horticulture must consider capture of genetic diversity, data stewardship, cultivation, and propagation. But here, we see a case where leveraging limited legacy assets and market forces add a potential strategic contribution to long-term in situ conservation. Palma corcho will always be a beautiful, unique plant with special appeal for the gardener-but sometime soon, no gardener will be able to call it rare or expensive.

\section{Literature cited}

Bergquist, J. 2010. Realistic disaster planning for collections management. Public Garden 25(4):30-31.

Bergquist, J.M. 2009. The development of a natural disaster planning template for use in plant collections management. Univ. Delaware, Newark, MS Thesis.

Botanic Gardens Conservation International. 2011. PlantSearch. 20 June 2011. $<$ http://www.bgci.org/plant_search.php>.

Bösenberg, J.D. 2009. Microcycas calocoma. In: International Union for the Conservation of Nature, 2010. IUCN Red List of Threatened Species. Version 2010.4. 3 May 2011. <http://www. iucnredlist.org/apps/redlist/details/ $42107 / 0>$.

Broome, T. 2007. Coffee, cycads' new best friend? Cycad Nwsl. 30:44-46.

Bulte, E.H. and G.C. van Kooten. 1999. Economic efficiency, resource conservation and the ivory trade ban. Ecol. Econ. 28:171-181.

Calonje, C., C. Husby, and M. Calonje. 2010. Germination and early seedling growth of rare Zamia spp. in organic and inorganic substrates: Advancing ex situ conservation horticulture. HortScience 45:679-683.

Calonje, M. 2007. History, growth rate, and phenology of Microcycas calocoma in south Florida. Cycad Nwsl. 30:20-21.

Chandra, B., L. Palni, and S. Nandi. 2006. Propagation and conservation of Picrorbiza kurrooa Royle ex Benth.: An endangered Himalayan medicinal herb of high commercial value. Biodivers. Conserv. 15:2325-2338.

Chavez, R. and J.A. Genaro. 2005. A new species of Pharaxonotha (Coleoptera: Erotylidae), probable pollinator of the endangered Cuban cycad, Microcycas calocoma (Zamiaceae). Insecta Mundi 19:142-150.

Cuban National Horticultural Society. 1911. Fifth annual report of the Cuban National Horticultural Society. CNHS, Havana, Cuba.

de Melo, J., E. de Amorim, and U. de Albuquerque. 2009. Native medicinal plants commercialized in Brazil: Priorities for conservation. Environ. Monit. Assess. 156:567-580. 
Dehgan, B. 1999. Propagation and culture of cycads: A practical approach. Acta Hort. 486:123-131.

Donaldson, J.S. 2003. Cycads: Status survey and action plan. International Union for Conservation of Nature, Gland, Switzerland.

Dosmann, M.S. and P. Del Tredici. 2003. Plant introduction, distribution and survival: A case study of the 1980 Sino-American botanical expedition. Bioscience 53:588597.

Florida Nursery, Growers and Landscape Association. 2011. Botanical Auctions. 16 June 2011. <http://www.botanicalauctions. com/auction/index.php>.

Gayer, D. n.d. A tale of two cycads. Vizcaya Archives, Miami, FL.

Griffith, P. and C. Husby. 2010. The price of conservation: Measuring the mission and its cost. BG Journal 7:12-14.

Griffith, M.P. and M. Calonje. 2007. Ex situ horticultural conservation of Cycas micronesica, an endangered cycad species. Assn. Zoological Hort. 2007 Conf. Proc. p. 8-9.

Griffith, M.P., M.A. Calonje, D.W. Stevenson, C.E. Husby, and D.P. Little. 2011a. Time, place, and relationships: Cycad phenology in a phylogenetic and biogeographic context. Mem. N.Y. Bot. Gard. (In press).

Griffith, M.P., C.E. Husby, and M. Calonje. 2010. Cycad Collections Development in the Modern Context: Challenges, Opportunities, Investments and Outcomes. 1 July 2011. <http://www.bgci.org/files/ Dublin2010/papers/Griffith-M-Patrick. pdf>.

Griffith, M.P., C.E. Lewis, and J. FranciscoOrtega. 2011b. Palm conservation at a botanic garden: A case study of the keys thatch palm. Palms 55:93-101.

Griffith, M.P., L.R. Noblick, J.L. Dowe, C.E. Husby, and M. Calonje. 2008. Cyclone tolerance in new world Arecaceae: Biogeographic variation and abiotic natural selection. Ann. Bot. (Lond.) 102:591-598.

Hanna, W.W. 1994. Pollen storage in frostless and conventional frost-forming freezers. Crop Sci. 34:1681-1682.

Hauser, E.J.P. and J.H. Morrison. 1964. The cytochemical reduction of nitro blue tetrazolium as an index of pollen viability. Amer. J. Bot. 51:748-752.

Hedrick, P.W. and S.T. Kalinowski. 2000. Inbreeding depression in conservation biology. Annu. Rev. Ecol. Syst. 31:139-162.

Hersch-Martínez, P. 1995. Commercialization of wild medicinal plants from southwest Puebla, Mexico. Econ. Bot. 49:197-206.

Homma, A.K.G. 1992. The dynamics of extraction in Amazonia: A historical perspective. Adv. Econ. Bot. 9:23-31.

Jones, D.L. 1993. Cycads of the world. Smithsonian Institution Press, Washington, DC.

Kiem, S. 1963. FTG superintendent recalls trip to Castro Cuba to find rare cycad. Fairchild Trop. Garden Bul. 18:92-97.

Kramer, A., A. Hird, K. Shaw, M. Dosmann, and R. Mims. 2011. Conserving North America's Threatened Plants: Progress Towards Target 8 of the Global Strategy for Plant Conservation. I July 2011. <http://www.bgci.org/files/UnitedStates/ NACA/naca_report_final.pdf>.

Lawrence, M.J., D.F. Marshall, and P. Davies. 1995. Genetics of genetic conservation. 2: Sample size when collecting seed of cross-pollinating species and the information that can be obtained from the evaluation of material held in gene banks. Euphytica 84:101-107.

Lazcano, J. 2007. Notes on Microcycas calocoma. Cycad Nwsl. 30:15-18.

Lazcano-Lara, J. 2004. Biolog1a poblacional y aspectos ecologicos de Microcycas calocoma (Miq.) A. DC. en la Sierra de La Caoba, Vinales. Jardın Botanico Nacional, Univ. de La Habana, Havana, Cuba, MS Thesis.

Maunder, M., K. Havens, E.O. Guerrant, and D.A. Falk. 2004. Ex situ methods: A vital but underused set of conservation resources, p. 3-20. In: E.O. Guerrant, K. Havens, and M. Maunder (eds.). Ex situ Plant Conservation: Supporting species survival in the wild. Island Press, Washington, DC.

Namoff, S., C.E. Husby, J. FranciscoOrtega, L.R. Noblick, C.E. Lewis, and M.P. Griffith. 2010. How well does a botanical garden collection of a rare palm capture the genetic variation in a wild population? Biol. Conserv. 143:1110-1117.

Norstog, K.J. and T.J. Nicholls. 2002. The biology of the cycads. Cornell University Press, Ithaca, NY.

Oldfield, S. 2010. Botanic gardens: Modernday arks. MIT Press, Cambridge, MA.

Peña, E., P.I. Lopez, J. Lazcano, A. Leiva, and U.S. Seal. 1998. Memorias del primer taller para la conservacion, analisis y manejo planificado de plantas silvestres Cubanas, 13-15 abril. IUCN/SSC Conservation and Breeding Specialist Group, Apple Valley, MN.
Pinares, A., J. Gonzalez-Astorga, A.P. Vovides, J. Lazcano, and W.A. Vendrame. 2009. Genetic diversity of the endangered endemic Microcycas calocoma (Miq.) A. DC (Zamiaceae, Cycadales): Implications for conservation. Biochem. Syst. Ecol. 37:385-394.

Prakash, S., N. Grobbelaar, and J. Van Staden. 2008. Diversity in Encephalartos woodii collections based on random amplified DNA markers and inter-specific sequence repeats. S. Afr. J. Bot. 74:341-344.

Radford, E., M. Dosmann, and D. Rae. 2003. The management of 'ad hoc' ex situ conservation status species at the Royal Botanic Garden Edinburgh: A review of options. Sibbaldia 1:43-80.

Smith Olsen, C. and H. Overgaard Larsen. 2003. Alpine medicinal plant trade and Himalayan mountain livelihood strategies. Geogr. J. 169:243-254.

Sturrock, W.D. 1915. Letter to Paul Chalfin, 8 June 1915. Vizcaya Archives, Miami, FL.

Tang, W. 1993. Heat and odour production in cycad cones and their role in insect pollination, p. 140-147. In: D.W. Stevenson and K.J. Norstog (eds.). Proc. Cycad 90: 2nd Intl. Conf. Cycad Biol., vol. 2. Palm and Cycad Societies of Australia, Milton, Brisbane, Australia.

Tang, W., A. Lindström, and N. Liu. 2004. Cycas debaoensis conservation project in China, p. 77-83. In: A. Lindström (ed.). Proc. Cycad 2002. Nong Nooch Tropical Garden, Bangkok, Thailand.

Tang, W., L. Sternberg, and D. Price. 1987. Metabolic aspects of thermogenesis in male cones of five cycad species. Amer. J. Bot. 74:1555-1559.

Terry, I., G. Walter, C. Hull, C. Moore, and R. Roemer. 2007. Odor-mediated push-pull pollination in cycads. Science 318:70.

Trueman, S.J., G.S. Pegg, and J. King. 2007. Domestication for conservation of an endangered species: The case of the wollemi pine. Tree For. Sci. Biotechnol. $1: 1-10$.

Vovides, A.P. 2010. The Mexican living cycad collection at the Jardín Botánico Francisco Javier Clavijero. 1 July 2011. <http://www.bgci.org/files/Dublin2010/ papers/Vovides-Andrew-P.pdf>.

Vovides, A.P., N. Ogata, V. Sosa, and E. Peña. 1997. Pollination of endangered Cuban cycad Microcycas calocoma (Miq.) A. DC. Bot. J. Linn. Soc. 25:201-210.

Whitelock, L.M. 2002. The cycads. Timber Press, Portland, OR. 